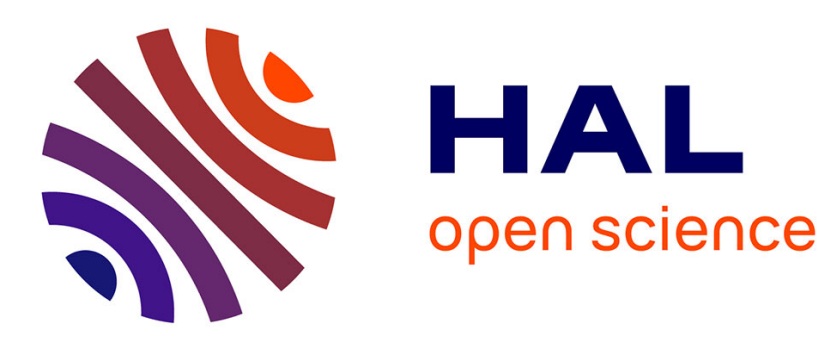

\title{
Oxolinic Acid Binding at Goethite and Akaganeite Surfaces: Experimental Study and Modeling
}

Remi Marsac, Sébastien Martin, Jean-François Boily, Khalil Hanna

\section{To cite this version:}

Remi Marsac, Sébastien Martin, Jean-François Boily, Khalil Hanna. Oxolinic Acid Binding at Goethite and Akaganeite Surfaces: Experimental Study and Modeling. Environmental Science and Technology, 2016, 50 (2), pp.660-668. 10.1021/acs.est.5b04940 . hal-01904132

HAL Id: hal-01904132

https://hal-univ-rennes1.archives-ouvertes.fr/hal-01904132

Submitted on 24 Oct 2018

HAL is a multi-disciplinary open access archive for the deposit and dissemination of scientific research documents, whether they are published or not. The documents may come from teaching and research institutions in France or abroad, or from public or private research centers.
L'archive ouverte pluridisciplinaire HAL, est destinée au dépôt et à la diffusion de documents scientifiques de niveau recherche, publiés ou non, émanant des établissements d'enseignement et de recherche français ou étrangers, des laboratoires publics ou privés. 


\section{Oxolinic Acid Binding at Goethite and Akaganéite Surfaces: Experimental Study and Modeling}

Rémi Marsac, Sebastien MARTIN, Jean-François Boily, and Khalil Hanna

Environ. Sci. Technol., Just Accepted Manuscript • DOI: 10.1021/acs.est.5b04940 • Publication Date (Web): 17 Dec 2015

Downloaded from http://pubs.acs.org on December 18, 2015

\section{Just Accepted}

"Just Accepted" manuscripts have been peer-reviewed and accepted for publication. They are posted online prior to technical editing, formatting for publication and author proofing. The American Chemical Society provides "Just Accepted" as a free service to the research community to expedite the dissemination of scientific material as soon as possible after acceptance. "Just Accepted" manuscripts appear in full in PDF format accompanied by an HTML abstract. "Just Accepted" manuscripts have been fully peer reviewed, but should not be considered the official version of record. They are accessible to all readers and citable by the Digital Object Identifier (DOI®). "Just Accepted" is an optional service offered to authors. Therefore, the "Just Accepted" Web site may not include all articles that will be published in the journal. After a manuscript is technically edited and formatted, it will be removed from the "Just Accepted" Web site and published as an ASAP article. Note that technical editing may introduce minor changes to the manuscript text and/or graphics which could affect content, and all legal disclaimers and ethical guidelines that apply to the journal pertain. ACS cannot be held responsible for errors or consequences arising from the use of information contained in these "Just Accepted" manuscripts. 


\section{Oxolinic Acid Binding at Goethite and Akaganéite Surfaces: Experimental}

2

3

4

5

6

$7 \quad{ }^{1}$ Ecole Nationale Supérieure de Chimie de Rennes, UMR CNRS 6226, 11 Allée de Beaulieu, 8

9

10

11

12

13

14

15

16

17

18

19

20

21

22

23

\section{Study and Modeling}

.

4

Rémi Marsac $^{1}$, Sébastien Martin $^{1,2}$, Jean-François Boily $^{2}$, Khalil Hanna $^{1^{*}}$

6

8

${ }^{2}$ Department of Chemistry, Umeå University, Umeå, SE-901 87, Sweden.

10

* Corresponding author: Ecole Nationale Supérieure de Chimie de Rennes, 11 Allée de Beaulieu, F-35708 Rennes Cedex 7, France.

khalil.hanna@ensc-rennes.fr

Phone: +33223238027 / Fax: +33223238120
6

7

8

9

20




\section{Abstract}

25 Oxolinic acid (OA) is a widely used quinolone antibiotic in aquaculture. In this study, its 26 interactions with synthetic goethite $(\alpha-\mathrm{FeOOH})$ and akaganéite $(\beta-\mathrm{FeOOH})$ particle surfaces

27 were monitored to understand the potential fate of OA in marine sediments where these 28 phases occur. Batch sorption experiments, liquid chromatography (LC) analyses of 29 supernatants, Attenuated Total Reflectance-Fourier Transform InfraRed (ATR-FTIR) 30 spectroscopy and multi-site complexation (MUSIC) modeling were used to monitor OA 31 binding at these particle surfaces. Both LC and ATR-FTIR showed that adsorption did not 32 degrade $\mathrm{OA}$, and that $\mathrm{OA}$ adsorption was largely unaffected by $\mathrm{NaCl}$ concentrations (10-1000 $33 \mathrm{mM}$ ). This was explained further by ATR-FTIR suggesting the formation of metal-bonded 34 complexes at circumneutral to low $\mathrm{pHc}\left(=-\log \left[\mathrm{H}^{+}\right]\right)$and with a strongly hydrogen-bonded 35 complex at high pHc. The stronger OA binding to akaganéite can be explained both by the 36 higher isoelectric point/point-of-zero charge (9.6-10) of this mineral than of goethite (9.1-9.4), 37 and an additional OA surface complexation mechanism at the (010) plane. Geminal sites $38\left(\equiv \mathrm{Fe}\left(\mathrm{OH}_{2}\right)_{2}{ }^{+}\right)$at this plane could be especially reactive for metal-bonded complexes, as they 39 facilitate a mononuclear six-membered chelate complex via the displacement of two 40 hydroxo/aquo groups at the equatorial plane of a single Fe octahedron. Collectively, these 41 findings revealed that Fe-oxyhydroxides may strongly contribute to the fate and transport of 42 OA-type antibacterial agents in marine sediments and waters. 
44

45

46

47

48

49

50

51

52

53

54

\section{Introduction}

Oxolinic Acid (OA) belongs to a family of quinolone antibiotics that is commonly used in aquaculture as a prophylactic, or as a chemotherapy agent. ${ }^{1,2}$ Unabsorbed or excreted OA released into waters and/or accumulated in marine and freshwater sediments poses potential risks to public health and to aquatic life. ${ }^{3}$ Due to its frequent use in fish farming, concentrations of OA can be of the order of $0.01-2.50 \mathrm{ppm}$ in fresh or saline surface waters, 0.01-2.31 ppm in bottom waters, and even $1.81-426.31$ ppm in pond sediments. ${ }^{1,4,5}$ Moreover, Greek fish farms release $50 \mathrm{~kg}$ of OA annually to the Mediterranean Sea. ${ }^{4}$

In marine or freshwater sediments, soils and aquatic environments, the transport and mobility of quinolone antibiotics are strongly related to reactive oxide minerals through adsorption and redox reactions. ${ }^{6-14}$ In a study on oxolinic acid sorption on marine sediments Pouliquen and Le Bris ${ }^{15}$ concluded that while OA was not transformed in the sediments by abiotic or biotic processes, it can be sorbed to sediments containing reactive mineral surfaces. Among these reactive surfaces, iron oxyhydroxides, including goethite $(\alpha-\mathrm{FeOOH})$ and akaganéite $(\beta-\mathrm{FeOOH})$, are ubiquitous in marine environments. ${ }^{16,17}$ Akaganéite is a chlorinebearing iron oxyhydroxide with a hollandite-type (tunnel-like) structure containing $\mathrm{Cl}^{-}$ions residing in $4 \times 4 \mathrm{~nm}$ wide tunnels running along the length of acicular nano-sized particles. This phase can be generally found in environments rich in $\mathrm{Fe}(\mathrm{II})$ and $\mathrm{Cl}^{-}$, and as a natural corrosion product in high salinity environmental settings. ${ }^{18-21}$ Goethite is the most thermodynamically stable iron oxyhydroxide mineral and is reported to form through the transformation of metastable phases such as ferrihydrite, schwertmannite and akaganéite. ${ }^{22}$ Goethite was also shown to be the most common diagenetic iron oxyhydroxide in both marine and lake sediments. ${ }^{23}$

Although OA has been extensively used in industrial fish farming, and thus is frequently detected in surrounding waters or sediments, little is known about its molecular 
interactions with suspended particles or mineral constituents in sediments, which is necessary to accurately assess its fate in aquatic environments. In this study, interactions of OA with goethite and akaganéite particles were studied by batch experiments, surface complexation modeling, and vibration spectroscopic investigations. Effects of pHc $\left(4<-\log \left[\mathrm{H}^{+}\right]<11\right)$, salinity (10-1000 $\mathrm{mM} \mathrm{NaCl})$ and surface loading on OA binding mechanisms were resolved, and implications for the fate of $\mathrm{OA}$ in marine environments were proposed.

\section{Materials and methods}

\subsection{Chemicals}

All chemicals used were of pro-analytical quality or better and were purchased from Sigma-Aldrich. An OA (purity > 99\%) stock solution was prepared by dissolving $30 \mathrm{mg}$ (115 umoles) $\mathrm{OA}$ in $20 \mathrm{~mL}$ of $1 \mathrm{M} \mathrm{NaOH}$, then diluted to $1 \mathrm{~L}$ with ultrapure water.

\subsection{Synthesis and characterization of goethite and akaganéite particles}

Goethite and akaganéite particles were synthesized as described in previous studies. $^{24,25}$ The synthesis procedure is given in detail in the supporting information (SI). The obtained particles were characterized by particle size and B.E.T. specific surface area $\mathrm{N}_{2}(\mathrm{~g})$ adsorption measurements, chemical analysis, transmission electron microscopy (TEM) and Xray diffraction (XRD). The B.E.T. specific surface area of the synthetic goethite and akaganéite were 95 and $239 \mathrm{~m}^{2} / \mathrm{g}$, respectively. Other characteristic properties of these solids are summarized in the SI.

\subsection{Batch experiments and liquid chromatography analysis}

Because high background electrolyte solutions can affect $\mathrm{pH}$ measurements, ${ }^{27}$ the $\mathrm{pH}$ electrode was calibrated to measure the molarity of the proton $\left(-\log \left[\mathrm{H}^{+}\right]\right.$, noted $\left.\mathrm{pHc}\right)$ using 
94 solutions of known $\left[\mathrm{H}^{+}\right]\left(10^{-5}-10^{-3} \mathrm{M}\right)$ at different $[\mathrm{NaCl}]$, and the results are provided in this 95 form in this study.

96 OA solubility experiments (undersaturation direction) were conducted by suspending 97 solid $\mathrm{OA}(\sim 3-5 \mathrm{mg})$ in $10 \mathrm{~mL}$ of solution in $100 \mathrm{mM} \mathrm{NaCl}$ as a function of $\mathrm{pHc}$. The 98 suspensions were equilibrated for $24 \mathrm{~h}$, after which the supernatants were filtered $(0.2 \mu \mathrm{m})$ 99 and OA concentrations were measured with high pressure liquid-chromatography coupled 100 with UV detection (HPLC-UV). As discussed later, OA solubility is relatively low $(\sim 10 \mu \mathrm{M})$ 101 at acidic pHc, in agreement with previous studies. ${ }^{26}$

102 An akaganéite (stock) suspension was prepared as previously reported. ${ }^{25}$ Aliquots of 103 the original stock suspension $\left(21 \mathrm{~g} / \mathrm{L}, 5023 \mathrm{~m}^{2} / \mathrm{L}\right)$ were used to prepare four suspensions $(2.1$ $\left.104 \mathrm{~g} / \mathrm{L}, 502.3 \mathrm{~m}^{2} / \mathrm{L}\right)$ in different concentrations of $\mathrm{NaCl}(10,100,450$ or $1000 \mathrm{mM})$. These 105 suspensions were equilibrated for over 30 days to ensure complete ion exchange between bulk 106 akaganéite and solution ions, as previously explained by Kozin and Boily. ${ }^{25}$ Goethite 107 suspensions were prepared at the chosen ionic strength just before adding OA.

108 Batch adsorption experiments were performed under conditions of varied reaction 109 time, OA concentration, $\mathrm{pHc}$ and ionic strength. Kinetic studies were conducted for $\mathrm{pHc}=6$, $110[\mathrm{NaCl}]=100 \mathrm{mM},[\mathrm{OA}]_{\mathrm{tot}}=50 \mu \mathrm{M}$ with an equivalent surface area of solids, i.e. $50 \mathrm{~m}^{2} / \mathrm{L}$ of 111 goethite or akaganéite. All batch experiments were performed under an atmosphere of $\mathrm{N}_{2}(\mathrm{~g})$ 112 to purge dissolved $\mathrm{CO}_{2}$ from the aqueous solutions. Briefly, solutions of 1 to $100 \mu \mathrm{M} \mathrm{OA}$ 113 were mixed with goethite or akaganéite $\left(50 \mathrm{~m}^{2} / \mathrm{L}\right)$ at the desired concentration of $\mathrm{NaCl}(10$, 114100,450 or $1000 \mathrm{mM}$ ). pHc was thereafter adjusted to the desired value by addition of $0.1 \mathrm{M}$ $115 \mathrm{HCl}$ solutions (the initial $\mathrm{pHc}$ value was about 10). In another set of experiments, adsorption 116 isotherms were collected at $\mathrm{pHc}=6.1 \pm 0.1$, for $[\mathrm{OA}]_{\text {tot }}$ concentrations in the $1-50 \mu \mathrm{M}$ range 117 for goethite, and the $3-100 \mu \mathrm{M}$ range for akaganéite. All suspensions were then equilibrated 118 for $24 \mathrm{~h}$ and the supernatants filtered $(0.2 \mu \mathrm{m})$ prior to soluble OA determination by HPLC- 
119 UV. Desorption tests $(\mathrm{pHc}=11)$ were conducted under various experimental conditions as a 120 means to verify the mass balance of OA in the systems under study.

121 Soluble OA concentrations were determined by a Waters 600 controller high 122 performance liquid chromatography (HPLC) system equipped with an auto sampler (Waters 123717 plus $)$, a C18 column $(250 \mathrm{~mm} \times 4.6 \mathrm{~mm}$ i.d., $5 \mu \mathrm{m})$ and a UV detector $(275 \mathrm{~nm}$, Waters 124 2489). The mobile phase was a mixture of water/acetonitrile $(60: 40 \mathrm{v} / \mathrm{v})$ containing $0.1 \%$ of 125 formic acid. The flow rate of the mobile phase was set at $1 \mathrm{~mL} / \mathrm{min}$ in the isocratic mode. 126 Finally, the complete experimental solubility and sorption datasets are provided in SI (Tables $127 \mathrm{~S} 1, \mathrm{~S} 2$ and S3).

128

\subsection{ATR-FTIR spectroscopy}

Attenuated total reflectance-Fourier transform infrared (ATR-FTIR) spectra were

131 recorded between in the $780-4000 \mathrm{~cm}^{-1}$ region on an IS50 Nicolet spectrometer equipped with

132 a $\mathrm{KBr}$ beamsplitter and a liquid Nitrogen cooled MCT (Mercury Cadmium Telluride)

133 detector. A nine-reflection diamond ATR accessory (DurasamplIR TM, SensIR Technologies)

134 was used for acquiring spectra of wet samples. The resolution of the single beam spectra was $1354 \mathrm{~cm}^{-1}$.

136 Three series of experiments were conducted with akaganéite for: (i) $5<\mathrm{pH}<$ with $137[\mathrm{OA}]_{\text {tot }}=50 \mu \mathrm{M}$ and $[\mathrm{NaCl}]=100 \mathrm{mM}$, (ii) $10 \leq[\mathrm{NaCl}] \leq 1000 \mathrm{mM}$ with $[\mathrm{OA}]_{\text {tot }}=50 \mu \mathrm{M}$ and $138 \mathrm{pHc}=6$ and (iii) $20 \leq[\mathrm{OA}]_{\text {tot }} \leq 50 \mu \mathrm{M}$ with $\mathrm{pHc}=6$ and $[\mathrm{NaCl}]=100 \mathrm{mM}$. For goethite, the 139 same experiments were conducted except for $\mathrm{pHc}<7$, where $[\mathrm{OA}]_{\text {tot }}=20 \mu \mathrm{M}$ because OA 140 partially precipitated at $50 \mu \mathrm{M}$ (see below). Prior to ATR-FTIR analysis, tubes from batch 141 sorption experiments were centrifuged at $10,000 \mathrm{~g}$ for $30 \mathrm{~min}$. Wet mineral pastes were 142 directly and uniformly applied to the diamond ATR crystal then covered with a lid of a flow143 through cell to prevent the evaporation of water. ATR-FTIR spectra were then recorded 
144 immediately. Reference spectra include those for pure water, the filtered $(0.2 \mu \mathrm{m})$ supernatant

145 from each batch adsorption experiment, as well as $\mathrm{OA}_{(\mathrm{s})}$ in its solid form but covered with a 146 drop of water to apply it more uniformly. A reference spectrum of aqueous OA was also 147 acquired from a $10 \mathrm{mM} \mathrm{OA}(2.5 \mathrm{~g} / \mathrm{L})$ solution in $1 \mathrm{M} \mathrm{NaOH}$. This solution ensured a 148 sufficiently high concentration of $\mathrm{OA}_{(\mathrm{aq})}^{-}$for ATR-FTIR analysis. Otherwise, OA was not 149 detected in any of the supernatants given its low solubility. All spectra are shown for the 150 fingerprint $1200-1800 \mathrm{~cm}^{-1}$ region only. Additional ATR-FTIR measurements of $\mathrm{OA}$ in $\mathrm{D}_{2} \mathrm{O}$ $151 \mathrm{OA}_{(\mathrm{aq})}^{-}$, OA-goethite $(\mathrm{pD}=7.81)$ and OA-akanagéite $(\mathrm{pD}=8.51)$ in $\mathrm{D}_{2} \mathrm{O}$ were also carried 152 out to resolve bands arising from moieties that are directly affected by exchange or hydrogen153 bonding with water. Sample preparation is detailed further in the Supporting Information (SI).

\subsection{Surface complexation modeling}

156 Predictions of sorption vs $\mathrm{pHc}$ were made using the multi-site complexation (MUSIC) 157 model approach. ${ }^{28}$ The geochemical speciation code PHREEQC (version 2) ${ }^{29}$ was used for 158 surface complexation calculations. PHREEQC includes the three plane model (TPM). 159 Charges of the adsorbates were distributed among the $0\left(\mathrm{H}^{+}\right.$, metal-bonded $\left.\mathrm{OA}\right), 1$ (hydrogenbonded $\mathrm{OA})$, and $2\left(\mathrm{Na}^{+}, \mathrm{Cl}^{-}\right)$planes of the TPM. The TPM requires two capacitances for the

1610 - and the 1-plane, $\mathrm{C}_{1}$ and $\mathrm{C}_{2}$, respectively (see SI for more details). PhreePlot ${ }^{30}$ was used to 162 estimate parameters for OA sorption to goethite and akaganéite. Using a modified Marquardt163 Levenberg procedure, ${ }^{31}$ PhreePlot provides a statistical uncertainty for the estimated 164 parameters, which are reported in this study. For goethite or akaganéite, different types of 165 surface sites can exist depending on the proportion of crystal planes, which should have 166 different binding affinities. All information concerning the dominant crystal planes of 167 particles and corresponding site densities are given in the SI. Charge densities and 168 corresponding electrostatic interactions at particle termination (i.e. (021) plane of goethite and 
169 (010) plane of akaganéite) were computed individually, as well as formation constants of all

170 surface species are reported in Table 1. Surface complexation constants reported for OA were 171 corrected according to Venema et al. $^{32}$ ( see also $^{33}$ ).

172

173 3. Results and Discussion

174 3.1. Batch experiments

175 Kinetic batch adsorption experiments conducted over a 7-day period showed that 176 equilibrium was achieved within $2 \mathrm{~h}$ of reaction time (Figure S1). Desorption tests also 177 showed that OA was removed only by adsorption or precipitation, and that breakdown by, for example, oxidation, did not occur under the experimental conditions of this study. Adsorption curves for $10 \mu \mathrm{M}$ OA solutions reacted in $50 \mathrm{~m}^{2} / \mathrm{L}$ mineral suspensions

180 (Fig. 1a,b) revealed greater OA loadings on akaganéite than on goethite. At pHc $<6.5$, only $181 \sim 70 \%$ of OA sorbs onto goethite (Fig. 1a, Table S1) whereas an almost complete uptake was 182 achieved on akaganéite at $\mathrm{pHc}=7.5$ ( $\sim 98 \%$; Fig. 1b, Table S2). OA adsorption was greatest 183 under acidic to circumneutral $\mathrm{pH}$, and lowest under alkaline conditions, as typically 184 encountered for anionic ligands. Furthermore, an insignificant effect of $\mathrm{NaCl}$ concentration was detected, so OA binding should predominantly occur as strong metal-bonded complexes with surface $\mathrm{Fe}$ sites and/or directly hydrogen-bonded complexes with surface hydroxo

187 groups. Resistance of the latter to variations in ionic strength was notably demonstrated by 188 Johnson et $a .^{34}$. Weaker outer-sphere complexes should, on the other hand, be more affected 189 by variations in ionic strength. ${ }^{35}$ This observation is consistent with the adsorption of 190 flumequine (analogous structure of OA) to goethite where the effect of ionic strength was also 191 negligible $(1<[\mathrm{NaCl}]<100 \mathrm{mM}) .{ }^{14}$ Our explanation for the greater OA loadings achieved in 192 akaganéite is two-fold. First, we note that while reactive site density of these two minerals 193 under study are highly comparable (see details in SI), the point-of-zero charge of akaganéite 
$194(9.6-10)^{25}$ is higher than that of goethite $(9.1-9.4)^{24,36}$. Second, geminal $\equiv \mathrm{Fe}\left(\mathrm{OH}_{2}\right)_{2}{ }^{+}$groups of 195 the (010) plane of akaganéite are expected to be strongly reactive sites for binding anionic 196 species. $^{25,37,38}$ The site density of these groups is estimated at 0.18 site $/ \mathrm{nm}^{2}$ (i.e. $5 \% \times 3.53$ 197 site $/ \mathrm{nm}^{2}$ ), which may favor an additional OA removal mechanism, as will be suggested 198 further by modeling (Fig. $1 \mathrm{~b}$ and $1 \mathrm{~d})$.

199 In case of goethite $(\mathrm{pHc}<7)$, the plateau is found higher for $[\mathrm{OA}]_{\text {tot }}=50 \mu \mathrm{M}(\sim 85 \%)$ 200 than for $[\mathrm{OA}]_{\mathrm{tot}}=10 \mu \mathrm{M}(\sim 70 \%)$ (Fig. 1a and 1c, Table S1), i.e. OA loading is more than 5 201 times larger at $50 \mu \mathrm{M}$ than at $10 \mu \mathrm{M}$, which may suggest an additional removal mechanism 202 such as surface or bulk precipitation of OA in this pHc range. The latter possibility was tested 203 by conducting solubility experiments of OA at different pHc values (Fig. 2a, Table S3). 204 Additionally, the OA solubility was calculated with PHREEQC using the acidity constant $205\left(\mathrm{~K}_{\mathrm{a}}\right)$ value from the IUPAC stability constant database ${ }^{39}$ and the solubility constant $\left(\mathrm{K}_{\mathrm{s}}\right)$ fitted 206 to our data with Phreeplot:

$207 \mathrm{OAH}_{(\mathrm{s})} \rightleftharpoons \mathrm{OAH}_{(\mathrm{aq})} \quad ; \quad \mathrm{K}_{\mathrm{s}}=10^{-5.06 \pm 0.07}$

$208 \mathrm{OAH}_{(\mathrm{aq})} \rightleftharpoons \mathrm{OA}^{-}+\mathrm{H}^{+} ; \quad \mathrm{K}_{\mathrm{a}}=10^{-6.92}$

209 The experimental solubility values are in good agreement with both calculated (Fig. 2a) and 210 literature data (e.g. $23 \mu \mathrm{M}$ at $\mathrm{pH}=7) .{ }^{26}$ The equilibrium OA concentrations $\left([\mathrm{OA}]_{\mathrm{aq}}\right)$ in the 211 presence of goethite or akaganéite at $[\mathrm{OA}]_{\mathrm{tot}}=50 \mu \mathrm{M}$ are also plotted in Figure $2 \mathrm{a}$. In contact 212 with akaganéite, $[\mathrm{OA}]_{\mathrm{aq}}$ is below the solubility limit for all $\mathrm{pHc}$ tested, ruling out the bulk 213 precipitation in this experimental set. $[\mathrm{OA}]_{\mathrm{aq}}$ values in goethite are however closer to the 214 solubility curve at $\mathrm{pHc}<7.5$, a result possibly explaining the larger loadings achieved at $215[\mathrm{OA}]_{\mathrm{tot}}=50 \mu \mathrm{M}$. Accordingly, $[\mathrm{OA}]_{\mathrm{aq}}$ values measured at low ligand loadings $\left([\mathrm{OA}]_{\mathrm{tot}}=10\right.$ $216 \mu \mathrm{M})$ are below the OA solubility limit (Fig. 2a).

217 Adsorption isotherms (Fig. 2b) add further validation to solubility data where a sharp 218 rise in $\mathrm{OA}$ removal with goethite occurred at $\mathrm{pHc}=6.1 \pm 0.1$ and $[\mathrm{OA}]_{\mathrm{aq}} \approx 10 \mu \mathrm{M}$, 
corresponding to the solubility limit of OA. The OA adsorption isotherm for akaganéite does

224 225

226

227 not, on the other hand, reach this solubility limit, but rather reaches a maximal loading corresponding to $\mathrm{Q}_{\max }=1.14 \mathrm{OA} / \mathrm{nm}^{2}$. This value was obtained by modeling OA-akaganéite data with the Langmuir adsorption isotherm:

$$
[O A]_{\text {sorbed }}=Q_{\max } \frac{K_{L} \times[O A]_{a q}}{1+K_{L} \times[O A]_{a q}}
$$

with an adsorption constant of $\mathrm{K}_{\mathrm{L}}=0.53 \mu \mathrm{M}^{-1}$ (see the fit with the Langmuir equation in Fig. $\mathrm{S} 2$ ). As this $\mathrm{Q}_{\max }$ value is about one-third our estimated reactive site density at $\mathrm{FeOOH}$ surfaces (i.e. $\sim 3-\mathrm{OH} / \mathrm{nm}^{2}$ ), OA surface complexes binding may realistically involve two or three $-\mathrm{OH}$ sites. The molecular-level nature of these interactions will however be addressed in greater detail in the following section.

\subsection{ATR-FTIR Spectroscopic investigations}

\subsection{1. $\mathrm{OA}_{(s)}$ and $\mathrm{OA}_{(a q)}^{-}$in $1 \mathrm{M} \mathrm{NaOH}$}

The ATR-FTIR spectra of solid and soluble OA (Fig. 3) were used as a basis for assigning surface-bound OA species. Owing to the low solubility of OA, band assignments in the soluble species were made from a $1 \mathrm{M} \mathrm{NaOH}$ solution (Fig. 3).

The absorption band of $\mathrm{OA}_{(\mathrm{s})}$ and $\mathrm{OA}_{(\mathrm{aq})}$ at $1040 \mathrm{~cm}^{-1}$ (see Figure S3) corresponds to the stretching modes of the ether group $\left(v_{\mathrm{C}-\mathrm{O}-\mathrm{C}}\right)$. The FTIR spectra of $\mathrm{OA}_{(\mathrm{s})}$ and $\mathrm{OA}_{(\mathrm{aq})}$ exhibit three bands with maximum absorbance between 1470 and $1510 \mathrm{~cm}^{-1}$. These bands are assigned to $\mathrm{C}=\mathrm{C}$ stretches $\left(v_{\mathrm{C}=\mathrm{C}, \text { ring }}\right)$ and $\mathrm{C}-\mathrm{H}$ bends $\left(\delta_{\mathrm{C}-\mathrm{H}, \mathrm{ring}}\right)$ in the aromatic and quinolinone rings. ${ }^{40}$ The intense band of $\mathrm{OA}_{(\mathrm{s})}$ at $1440 \mathrm{~cm}^{-1}$, which disappears in the spectrum of $\mathrm{OA}_{(\mathrm{aq})}$, may be attributed to perturbation of $v_{\mathrm{C}=\mathrm{C} \text {,ring }}$ or $\delta_{\mathrm{C}-\mathrm{H} \text {,ring }}$ due to intermolecular interaction in $\mathrm{OA}_{(\mathrm{s})}$. The major difference between ATR-FTIR spectra of $\mathrm{OA}_{(\mathrm{s})}$ and $\mathrm{OA}_{(\mathrm{aq})}$ lies in the 
244 disappearance of two bands at 1705 and $1302 \mathrm{~cm}^{-1}$ from the deprotonation of the carboxyl 245 groups, i.e. disappearance of $\mathrm{C}=\mathrm{O}$ and $\mathrm{C}-\mathrm{OH}$ stretching modes of the carboxylic group. This 246 deprotonation gives, in turn, rise to the 1395 and $1586 \mathrm{~cm}^{-1}$ bands, which are respectively 247 assigned to symmetric $\left(v_{\mathrm{COO}, \mathrm{s}}\right)$ and asymmetric $\left(v_{\mathrm{COO}, \mathrm{as}}\right)$ stretching modes of the carboxylate, 248 and where $\Delta v=v_{\mathrm{COO}, \text { as }}-v_{\mathrm{COO}, \mathrm{s}}=191 \mathrm{~cm}^{-1}$. These values are, moreover, consistent with 249 previous studies on (fluoro)quinolones, ciprofloxacine (CIP) assigning $v_{\mathrm{COO}, \mathrm{s}}$ to a band at $250 \quad 1360-1380 \mathrm{~cm}^{-1},{ }^{6-11}$ and on ofloxacine (OFX) with a similar band at $1340 \mathrm{~cm}^{-1} \cdot{ }^{12-14}$ Our 251 spectrum for $\mathrm{OA}_{(\mathrm{aq})}$ also showed a distinct band at $1340 \mathrm{~cm}^{-1}$, but for reasons given later, it is 252 not assigned to $v_{\mathrm{COO}, \mathrm{s}}$. The absorption band at $1635 \mathrm{~cm}^{-1}$ is assigned to the stretching of the 253 quinolinone ring carbonyl group $\left(v_{\mathrm{C}=\mathrm{O} \text {,carbonyl }}\right)$, in accordance with previous spectroscopic 254 studies dedicated to (fluoro)quinolones. ${ }^{6-14,41}$

\subsubsection{OA-goethite}

Figure $3 \mathrm{a}$ shows the effect of $\mathrm{pHc}$ on the ATR-FTIR spectra of $20 \mu \mathrm{M}$ OA (for $\mathrm{pHc}<$ 7) or $50 \mu \mathrm{M} \mathrm{OA}$ (for $\mathrm{pHc}>7$ ) reacted with $50 \mathrm{~m}^{2} / \mathrm{L}$ goethite in $100 \mathrm{mM} \mathrm{NaCl}$. As shown in Figure S3a, the characteristic features of both $\mathrm{OA}_{(\mathrm{s})}$ and $\mathrm{OA}_{(\mathrm{aq})}$ were observed for OA-goethite samples at $\mathrm{pHc}=6.12$ for $[\mathrm{OA}]_{\mathrm{tot}}=50 \mu \mathrm{M}$. Only the characteristic of $\mathrm{OA}_{(\mathrm{aq})}$ appear for $\mathrm{pHc} \approx 6$ with $[\mathrm{OA}]_{\text {tot }} \leq 30 \mu \mathrm{M}$ and for $\mathrm{pH}>7$ with $[\mathrm{OA}]_{\text {tot }}=50 \mu \mathrm{M}$ (Fig. 2, Fig. S3), in agreement with our batch results. Especially, the absence of band at $1705 \mathrm{~cm}^{-1}$ suggests the presence of 263 deprotonated carboxylate groups.

At $\mathrm{pHc}=5.20$ and $6.39\left([\mathrm{OA}]_{\mathrm{tot}}=20 \mu \mathrm{M}\right)$, the band at $1395 \mathrm{~cm}^{-1}$ for $\mathrm{OA}_{(\mathrm{aq})}$ almost completely disappears and is replaced by a band centered at $1340 \mathrm{~cm}^{-1}$. This further supports

266 the assignment of $v_{\mathrm{COO}, \mathrm{s}}$ to the band at $1395 \mathrm{~cm}^{-1}$ in $\mathrm{OA}_{(\mathrm{aq})}$. The $v_{\mathrm{COO} \text {,as }}$ band might be slightly 267 blue-shifted $\left(1590 \mathrm{~cm}^{-1}\right)$, which gives $\Delta v \approx 250 \mathrm{~cm}^{-1}$, a value suggesting that only one oxygen 268 of the carboxylate binds to a surface $\mathrm{Fe}^{42}$ A blue shift of $v_{\mathrm{C}=0 \text {, carbonyl }}\left(1642 \mathrm{~cm}^{-1}\right)$ compared to 
$269 \mathrm{OA}_{(\mathrm{aq})}$ or $\mathrm{OA}_{(\mathrm{s})}$, also suggests the involvement of the keto group in the surface complex. A 270 similar shift from protonated $\mathrm{OA}_{(\mathrm{s})}$ to $\mathrm{Fe}(\mathrm{OA})_{3(\mathrm{~s})}$ was previously reported, where $\mathrm{OA}$ forms a 271 bidentate deprotonated complex with $\mathrm{Fe}^{3+}$ through the keto group and one carboxylate 272 oxygen. $^{41}$ The effects of $\mathrm{NaCl}$ concentration were also investigated for $20 \mu \mathrm{M}$ OA and 50 $273 \mathrm{~m}^{2} / \mathrm{L}$ goethite at $\mathrm{pHc} \approx 6$ (Fig. S3b). The weak ionic strength dependence on OA loadings and 274 ATR-FTIR spectra point to the predominance of OA species that are inner-spherically bound 275 to surface Fe sites (i.e. metal-bonded complex; MB), involving one oxygen of the carboxylate 276 and the oxygen of the keto group of OA. The involvement of both the carboxylate and keto 277 groups was proposed in previous studies dedicated to other quinolones binding to hydrous 278 ferric oxides ${ }^{6}$, magnetite ${ }^{9}$, hematite $^{11}$ and goethite ${ }^{10,14}$ or observed for metal cation-OA 279 complexes in water. ${ }^{41}$ The involvement of both the carboxylate and the phenolate of salicylate 280 and hydroxynaphthoate has also been evidenced at goethite surfaces. ${ }^{43-46} \mathrm{We}$ cannot directly 281 conclude from the ATR-FTIR spectra whether this complex involves one (Fig. 4a) or two 282 surface Fe atoms (Fig. 4b). Ideally, the steric constraints at the $(101) /(001)$ as well as the 283 (210) planes (Pnma group) should promote bridging between two Fe atoms separated by $3 \AA$ 284 from one another (Fig. 4b). Moreover, defects ought to expose additional possibilities for 285 mononuclear bidendate binding ( $c f$. six-membered chelate complexation, Fig. 4a), namely at 286 equatorial edges of a Fe octahedron. ${ }^{47}$ At $\mathrm{pHc}=7.60$ and $8.13\left([\mathrm{OA}]_{\text {tot }}=50 \mu \mathrm{M}\right)$, all bands remain unaffected compared to $288 \mathrm{pHc}=5.20$ and $6.39\left([\mathrm{OA}]_{\mathrm{tot}}=20 \mu \mathrm{M}\right)$, except the band at $1340 \mathrm{~cm}^{-1}$, which broadens and 289 whose full width at half maximum considerably increases with pHc. This band broadening is 290 taken as an indication of interactions of carboxylic groups with surface hydroxo groups with 291 various hydrogen-bond strengths ( $c f$. inhomogeneous band broadening ${ }^{48}$ ). An ATR-FTIR 292 spectrum of OA-goethite recorded in $\mathrm{D}_{2} \mathrm{O}$ for $\mathrm{pD}=7.81\left([\mathrm{OA}]_{\mathrm{tot}}=50 \mu \mathrm{M}\right)$ reveals that the $2931340 \mathrm{~cm}^{-1}$ band is the only one that is red-shifted in relation to the counterpart spectrum in 
$294 \mathrm{H}_{2} \mathrm{O}$ (Fig. S4), thus suggesting close interactions between carboxyl groups and O-D/H

295 moieties. These observations could thus point to a hydrogen-bonded (HB) complex involving

296 a direct hydrogen bond between carboxyl and keto moieties and surface (hydr)oxo groups.

297 This ionic strength independent complex thus contrasts with outer-sphere complexes

298 involving hydration waters. ${ }^{34}$ The increased intensity of the band at $1340 \mathrm{~cm}^{-1}$ suggests that a

299 strong form of hydrogen bonding is favored at high pHc whereas metal-bonded complexation

300 is favored at low pHc. This interpretation is in line with, for example, phthalate or

301 hydroxynaphthoate sorption to goethite ${ }^{44,46,47}$ where HB complexes are involved with two -

302 OH sites at the (101)/(001) planes (Fig. 4c).

303

304

\subsubsection{OA-akaganéite}

305 Figure $3 \mathrm{~b}$ shows the effect of $\mathrm{pHc}$ on ATR-FTIR spectra of $50 \mu \mathrm{M}$ OA interacting 306 with $50 \mathrm{~m}^{2} / \mathrm{L}$ akaganéite in $100 \mathrm{mM} \mathrm{NaCl}$. In agreement with our batch sorption results (Fig. 307 2), the characteristic features of $\mathrm{OA}_{(\mathrm{s})}$ are absent and therefore spectra must be attributed to 308 the surface complexed OA only. This is further confirmed by the analysis of OA-akaganéite 309 samples at lower $[\mathrm{OA}]_{\text {tot }}$ (down to $20 \mu \mathrm{M}$ ) at $\mathrm{pHc} \approx 6$ in $100 \mathrm{mM} \mathrm{NaCl}$ (Fig. S3c). The 310 spectra recorded at $\mathrm{pHc}=5.24$ and 6.20 are similar to those of OA-goethite when the amount 311 of precipitated OA is negligible, namely $v_{\mathrm{C}=0 \text {,carbonyl }}=1642 \mathrm{~cm}^{-1}$ and $v_{\mathrm{COO}, \mathrm{s}}=1330 \mathrm{~cm}^{-1}$. The

312 intense band observed for $\mathrm{OA}_{(\mathrm{aq})}$ at $1395 \mathrm{~cm}^{-1}$ disappears in the spectra recorded for OA313 akaganéite. The band of $v_{\mathrm{COO} \text {,as }}\left(1590 \mathrm{~cm}^{-1}\right)$ is also slightly blue-shifted compared to $\mathrm{OA}_{(\mathrm{aq})}$.

314 As for goethite, no significant effect of $\mathrm{NaCl}$ concentration on OA sorption to akaganéite can

315 be observed for $\mathrm{pHc} \approx 6$ (Fig. 1b), in accordance with the ATR-FTIR spectra (Fig. S3d).

316 Because these experimental conditions correspond to relatively high OA loadings $(\sim 0.5$

$317 \mathrm{OA} / \mathrm{nm}^{2}$ ), formation of a bridging complex between two surface Fe involving one oxygen of 318 the carboxylate and the oxygen of the keto group of OA (Fig. 4b) is likely expected at the 
$319(100) /(001)$ plane. In addition, the effect of OA surface coverage is investigated for [OA] $]_{\text {tot }}$ 320 down to $20 \mu \mathrm{M}$ (i.e. 0.24 adsorbed $\mathrm{OA}$ molecule per $\mathrm{nm}^{2}$ ) at $\mathrm{pHc} \approx 6$ and $100 \mathrm{mM} \mathrm{NaCl}$ (Fig.

321 S3c). At such loading, OA surface complexation to the (010) plane of akaganéite is expected 322 to be the major sorption mechanism (Fig. 2b, Fig. S2). No change in the coordination mode of 323 OA on akaganéite can be derived from our ATR-FTIR spectra when $[\mathrm{OA}]_{\text {tot }}$ varies. We 324 propose the formation of a MB surface complex involving one oxygen of the carboxylate and 325 the oxygen of the keto group of OA. Because both water molecules of the $\equiv \mathrm{Fe}\left(\mathrm{OH}_{2}\right)_{2}{ }^{+}$groups 326 can be released during the complexation of OA, we propose the formation of a six-membered 327 chelate, involving only one Fe (Fig. 4a). Therefore, the proposed structure for the OA 328 complex at the akaganéite (010) is presently based on crystallographic considerations. At high $\mathrm{pHc}$, we propose the predominance of a HB complex seen through a band at

$330 \sim 1350 \mathrm{~cm}^{-1}$. This band is broad and overlaps with the band at $1330 \mathrm{~cm}^{-1}$, especially for $\mathrm{pHc}=$ 3318.02 and 8.66. Its disappearance in $\mathrm{D}_{2} \mathrm{O}$ (Fig. S4) suggests that it is sensitive to the hydrogen 332 bonding environment of $\mathrm{OA}$, as in the case of goethite. As no significant ionic strength effects 333 were observed, OA could be directly hydrogen bonded to surface (hydr)oxo groups of 334 akaganéite (Fig. 4c, Fig. S3d).

335

\subsection{Surface complexation modeling}

According to the aforementioned crystallographic considerations and our 338 spectroscopic investigations, MB surface complexes at the goethite $(101) /(001)$ and (210)

339 planes (Pnma group) are expected to be comparable to those on the (100) and (001) planes of 340 akaganéite. OA forms a complex involving keto goup and one oxygen of the carboxylate 341 group, and it can be expressed in the following reaction:

342

$$
2 \mathrm{H}^{+}+2 \equiv \mathrm{FeOH}^{-0.5}+\mathrm{OA}^{-} \rightleftharpoons(\equiv \mathrm{Fe})_{2}(\mathrm{OA})^{0(+1 ; 0 ; 0)}+2 \mathrm{H}_{2} \mathrm{O} \quad \log \mathrm{K}_{\mathrm{MB}}
$$


345 where $(+1 ; 0 ; 0)$ denotes the charge variations at the 0 -, 1 - and 2-planes $\left(\Delta z_{0} ; \Delta z_{1} ; \Delta z_{2}\right)$. Only 346 singly coordinated $\left(\equiv \mathrm{FeOH}^{-0.5}\right)$ surface sites are considered to be involved in the latter 347 reaction given the propensity for ligand exchange of these sites. In the case of goethite, note 348 that $\equiv \mathrm{FeOH}^{-0.5}$ is used as a building block for different adsorption sites on the $(101) /(001)$ and 349 the (210) planes. Therefore, Eq. 4 does not denote the number of Fe(III) octahedra in a 350 complex, but only the number of $\equiv \mathrm{FeOH}^{-0.5}$ sites that may or may not be of the same $\mathrm{Fe}(\mathrm{III})$ 351 octahedron. $^{47}$ Our results cannot resolve the number of Fe(III) bound to OA explicitly with 352 the data on hand. In two recent MUSIC modeling studies, $\mathrm{CIP}^{10}$ and $\mathrm{OFX}^{14}$ were assumed to 353 bind only to the goethite (210) plane. However, from our data, we cannot exclude that OA 354 binds to the goethite $(101) /(001)$ planes.

355 Hydrogen-bonded (HB) complexation could form by involving various types of 356 surface sites. For the sake of simplicity, only singly $\equiv \mathrm{FeOH}^{-0.5}$ sites are considered: ${ }^{47}$

$$
2 \mathrm{H}^{+}+2 \equiv \mathrm{FeOH}^{-0.5}+\mathrm{OA}^{-} \rightleftharpoons\left(\equiv \mathrm{FeOH}_{2}\right)_{2}{ }^{+\ldots}(\mathrm{OA})^{-(+2 ;-1 ; 0)} \quad \log \mathrm{K}_{\mathrm{HB}}
$$

Preliminary tests showed that $\log \mathrm{K}_{\mathrm{HB}}$ and $\log \mathrm{K}_{\mathrm{MB}}$ values did not significantly differ for goethite. Therefore, they were constrained at the same value during the fit. The same strategy was applied for akaganéite. According to preliminary tests, it appeared unnecessary to include an additional charge distribution $(\mathrm{CD})^{28}$ term, unlike previous studies dedicated to $\mathrm{CIP}^{10}$ and

$364 \mathrm{OFX}^{14}$ that can bind to mineral surfaces under the zwitterion form.

365 Finally, to account for OA binding on the Fe sites of the (010) akaganéite plane, an 366 additional reaction was used, which we here describe as a geminal hydroxo/aquo 367 displacement reaction: 
371 In all of our modeling attempts, we neglect $\mathrm{Cl}^{-}$surface complexation to the akaganéite (010)

372 plane highlighted in earlier work ${ }^{25,37,38}$ as our data reveal no ionic strength dependence on OA 373 sorption. $\mathrm{Cl}^{-}$surface complexation to the akaganéite (010) plane may be too weak to compete 374 significantly with OA under the present conditions.

375 Surface complexation reactions and parameters for OA are reported in Table 1. 376 Results of the fit with PhreePlot are shown in Figure 1 for $\mathrm{pH}$-edges, and in Figure $2 \mathrm{~b}$ for 377 sorption isotherms. Our model almost predicts $[\mathrm{NaCl}]$ independent OA loading (Fig. 1a,b). 378 Loading effects and additional apparent OA uptake on goethite (Fig. 1c), actually due to the 379 bulk precipitation of OA are also well-predicted. Speciation calculations show that about $50 \%$ 380 of $50 \mu \mathrm{M}$ of $\mathrm{OA}$ precipitate in contact with goethite at $\mathrm{pHc}<6.5$, in agreement with 381 spectroscopic observations for samples prepared with high $[\mathrm{OA}]_{\text {tot }}$ and $\mathrm{pHc}<7$ (Fig. S3a). In 382 addition, the fraction of hydrogen-bonded OA at the goethite $(101) /(001)$ planes or akaganéite $383(100) /(001)$ planes increases with pHc (Fig. S5), consistently with our FTIR data. 384 Discrepancies between experimental and modeling results are observed for akaganéite at high 385 loadings $\left([\mathrm{OA}]_{\text {tot }}>20 \mu \mathrm{M}\right.$; Fig. 1d, Fig. 2a), probably due to steric hindrance and/or 386 electrostatic effects at high ligand loadings. Nevertheless, the model accurately predicts OA 387 sorption to akaganéite at environmentally relevant concentrations, i.e. lower OA loadings 388 ([OA $]_{\text {tot }}<20 \mu \mathrm{M}$; Fig. 1b, Fig. 2a).

389 The formation of a strong complex at the akaganéite (010) plane significantly 390 contributes to the overall uptake, even when the surface is almost saturated with OA. Geminal 391 sites $\left(\equiv \mathrm{Fe}\left(\mathrm{OH}_{2}\right)_{2}{ }^{+}\right)$at this plane could be especially reactive for metal-bonded binding, as they 392 facilitate a mononuclear six-membered chelate complex via the displacement of two 393 hydroxo/aquo groups at the equatorial plane of a single Fe octahedron. This form of 
394 interaction is generally excluded on the other dominant, yet idealized, $(001) /(101) /(210)$

395 planes of goethite and (100)/(001) of akaganéite where bridging metal-bonded and hydrogen-

396 bonded complexes are expected to be favored. The contribution of this complex is illustrated

397 e.g. in Figure $1 \mathrm{~d}$ for $[\mathrm{OA}]_{\mathrm{tot}}=50 \mu \mathrm{M}$, where $\equiv \mathrm{Fe}(\mathrm{OA})^{0}$ represents about $20 \%$ of OA uptake.

398 The model predicts that the latter complex prevails at low loadings (Fig. 2b) and high pHc. In

399 our experimental conditions, for $[\mathrm{OA}]_{\mathrm{tot}}=10 \mu \mathrm{M},[\mathrm{NaCl}]=100 \mathrm{mM}$ and $\mathrm{pHc}=8, \equiv \mathrm{Fe}(\mathrm{OA})^{0}$

400 accounts for $\sim 65 \%$ of OA uptake on akaganéite (Fig. 1b).

401

402

403

404

405

406

407

408

409

410

411

412

413

414

415

416

417

418

\section{Environmental implications}

Our combined kinetic, liquid chromatographic and ATR-FTIR investigations showed that only adsorption, and not oxidation, controls OA removal from aqueous suspensions of goethite and akaganéite. We demonstrated that OA binds to goethite or akaganéite surfaces through MB bidentate complex formation at circumneutral to low $\mathrm{pH}$ and through a strong HB complex at high $\mathrm{pH}$. The dominant MB complex involved direct binding between two surface $\mathrm{Fe}$ with keto and carboxylate oxygens of OA, predominantly in a bridging-type complex. This complexation mode was confirmed across a wide range of salinity (10 to 1000 $\mathrm{mM} \mathrm{NaCl}$ ) including seawater-like one (i.e. $599 \mathrm{mM}$ ). OA sorption to akaganéite is greater than to goethite, a result that can be attributed to the higher isoelectric point of this mineral, and also the formation of a strong complex at the akaganéite (010) plane. The contribution of this strong binding with geminal sites $\left(=\mathrm{Fe}\left(\mathrm{OH}_{2}\right)_{2}{ }^{+}\right)$of the akaganéite (010) plane in the overall sorption extent are strongly dependent on OA concentration. This sorption behavior may explain the strong retention of OA observed in sediments containing iron mineral surfaces, ${ }^{15}$ but also to mobile $\mathrm{FeOOH}$ particles or colloids present in freshwater and marine environments. This may also explain the slow transformation under dark conditions or high persistence of $\mathrm{OA}$ in pond waters ${ }^{49}$. These results may therefore have strong implications for 
419 the understanding of both colloidal and aqueous transport of antibacterial agents used in 420 aquaculture.

421

422

\section{Acknowledgements}

423

This research was supported by "Région Bretagne” (Contract SAD-ReSolEau (8256)) as well as by the Swedish Research Council (2012-2976 to JFB).

\section{Supporting Information Available}

427 Details of the synthesis and characterization of goethite and akaganéite particles, surface complexation modeling; additional results for kinetic sorption/desorption, OA sorption isotherms and ATR-FTIR spectroscopy in $\mathrm{H}_{2} \mathrm{O}$ or $\mathrm{D}_{2} \mathrm{O}$; tables with the whole experimental datasets. This information is available free of charge via the Internet at http://pubs.acs.org/.

\section{References}

433

434

435

436

437

438

439

440

441

442

443

444

445

446

447

448

449

450

451
1. Le, T. X.; Munekage, Y. Residues of selected antibiotics in water and mud from shrimp ponds in mangrove areas in Vietnam. Mar. Pollut. Bull., 2004, 49, 922-929.

2. Samuelsen, O.B. Pharmacokinetics of quinolones in fish: a review. Aquaculture, 2006, $255,55-75$.

3. Samuelsen, O.B.; Ervik, A.; Pursell, L.; Smith, P. Single-dose pharmacokinetic study of oxolinic acid and vetoquinol, an oxolinic acid ester, in Atlantic salmon (Salmo salar) held in seawater and in vitro antibacterial activity against Aeromonas salmonicida. Aquaculture, 2000, 187, 213-224.

4. Rigos, G.; Nengas, I.; Alexis, M.; Troisi, G.M. Potential drug (oxytetracycline and oxolinic acid) pollution from Mediterranean sparid fish farms. Aquat. Toxicol., 2004, 69, 281-288.

5. Tamtam, F.; Mercier, F.; Le Bot, B.; Eurin, J.; Tuc Dinh, Q.; Clement, M.; Chevreuil, M. Occurrence and fate of antibiotics in the Seine River in various hydrological conditions. Sci. Total Environ., 2008, 393, 84-95.

6. Gu, C.; Karthikeyan, K.G. Sorption of the Antimicrobial Ciprofloxacin To Aluminum and Iron Hydrous Oxides. Environ. Sci. Technol., 2005, 39 (23), 9166-9173.

7. Trivedi, P.; Vasudevan, D. Spectroscopic Investigation of Ciprofloxacin Speciation at the Goethite-Water Interface. Environ. Sci. Technol., 2007, 41 (9), 3153-3158. 
$452 \quad$ 8. Pei, Z.-G.; Shan, X.-Q.; Kong, J.-J.; Wen, B.; Owens, G. Coadsorption of ciprofloxacin

453

454

455

456

457

458

459

460

461

462

463

464

465

466

467

468

469

470

471

472

473

474

475

476

477

478

479

480

481

482

483

484

485

486

487

488

489

490

491

492

493

and $\mathrm{Cu}(\mathrm{II})$ on montmorillonite and kaolinite as affected by solution $\mathrm{pH}$, Environ. Sci.

Technol., 2010, 44 (3), 915-920.

9. Rakshit, S.; Sarkar, D.; Elzinga, E.J.; Punamiya, P.; Datta, R. Mechanisms of ciprofloxacin removal by nano-sized magnetite. J. Hazard. Mater., 2013, 246-247, 221-226.

10. Gu, X.; Tan, Y.; Tong, F.; Gu, C. Surface complexation modeling of coadsorption of antibiotic ciprofloxacin and $\mathrm{Cu}(\mathrm{II})$ and onto goethite surfaces. Chem. Eng. J., 2015, 269, 113-120.

11. Martin, S.; Shchukarev, A.; Hanna, K.; Boily, J.-F. Kinetics and Mechanisms of Ciprofloxacin Oxidation on Hematite Surfaces. Environ. Sci. Technol., 2015, 49 (20), $12197-12205$.

12. Goyne, K. W.; Chorover, J.; Kubicki, J. D.; Zimmerman, A. R.; Brantley, S. L. Sorption of the antibiotic ofloxacin to mesoporous and nonporous alumina and silica. J. Coll. Int. Sci., 2005, 283, 160-170.

13. Paul, T.; Machesky, M.; Strathmann, T. Surface Complexation of the Zwitterionic Fluoroquinolone Antibiotic Ofloxacin to Nano-Anatase $\mathrm{TiO}_{2}$ Photocatalyst Surfaces. Environ. Sci. Technol., 2012, 46 (21), 11896-11904.

14. Paul, T.; Liu, J.; Machesky, M.L.; Strathmann, T. Adsorption of zwitterionic fluoroquinolone antibacterials to goethite: A charge distribution-multisite complexation model. J. Coll. Int. Sci,. 2014, 428, 63-72.

15. Pouliquen, H.; Le Bris, H. Sorption of oxolinic acid and oxytetracycline to marine sediments. Chemosphere, 1996, 33 (5), 801-815.

16. Burns, R. G.; Burns ,V. M. Authigenic oxides. p. 875-914. In The Oceanic Lithosphere, Vol. 7, ed. Emiliani C., John Wiley \& Sons, New York. 1981.

17. Font, E.; Abrajevitch, A. Paleoenvironmental signature of the Deccan Phase-2 eruptions. Frontiers in Earth Sciences, 2014, 2(23), 1-5.

18. Selwyn, L. S.; Sirois, P. J.; Argyropoulos, V. The corrosion of excavated archaeological iron with details on weeping and akaganéite. Stud. Conserv., 1999, 44, 217-232.

19. Gismelseed, A.; Elzain, M.; Yousif, A.; Al Rawas, A.; Al-Omari, I. A.; Widatallah, H.; Rais, A. Identification of corrosion products due to seawater and fresh water. Hyperfine Interact., 2004, 156, 487-492.

20. Remazeilles, C.; Refait, P. On the formation of beta-FeOOH (akaganéite) in chloridecontaining environments. Corros. Sci., 2007, 49, 844-857.

21. Bibi, I.; Singh, B.; Silvester, E. Akaganéite $(\beta-\mathrm{FeOOH})$ precipitation in inland acid sulfate soils of south-western New South Wales (NSW), Australia. Geochim. Cosmochim. Acta, 2011, 75, 6429-6438.

22. Cornell, R. M.; Schwertmann, U. The iron oxides : structure, properties, reactions, occurrences, and uses; Wiley-VCH: Weinheim, 2003.

23. van der Zee, C.; Roberts, D.; Rancourt, D. G.; Slomp, C. P. Nanogoethite is the dominant reactive oxyhydroxide phase in lake and marine sediments. Geology, 2003, 31 (11), 993-996. 
494

495

496

497

498

499

500

501

502

503

504

505

506

507

508

509

510

511

512

513

514

515

516

517

518

519

520

521

522

523

524

525

526

527

528

529

530

531

532

533

534
24. Gaboriaud, F.; Ehrhardt, J. J. Effects of different crystal faces on surface charge of colloidal goethite $(\alpha-\mathrm{FeOOH})$ particles: an experimental and modeling study. Geochim. Cosmochim. Acta, 2003, 67, 967-983.

25. Kozin, P. A.; Boily J.-F. Proton Binding and Ion Exchange at the Akaganéite/Water Interface. J. Phys. Chem. C, 2013, 117, 6409-6419.

26. Tolls, J. Sorption of veterinary pharmaceuticals in soils: a review. Environ. Sci. Technol., 2001, 35 (17), 3397-3406.

27. Altmaier, M.; Metz, V.; Neck, V.; Müller, R.; Fanghänel, Th. Solid-liquid equilibria of $\mathrm{Mg}(\mathrm{OH})_{2(\mathrm{cr})}$ and $\mathrm{Mg}_{2}(\mathrm{OH})_{3} \mathrm{Cl} \cdot 4 \mathrm{H}_{2} \mathrm{O}_{(\mathrm{cr})}$ in the system Mg-Na-H-OH-Cl- $\mathrm{H}_{2} \mathrm{O}$ at $25{ }^{\circ} \mathrm{C}$. Geochim. Cosmochim. Acta, 2003, 67, 3595-3601.

28. Hiemstra, T.; van Riemsdijk, W. H. A surface structural approach to ion adsorption: the charge distribution (CD) model. J. Colloid Interf. Sci., 1996, 179, 488-508.

29. Parkhurst, D. L.; Appelo, C. A. J. User's guide to PHREEQC (Version 2) - a computer program for speciation, batch reaction, one-dimensional transport and inverse geochemical calculation; Denver, Colorado, 1999; p 312.

30. Kinniburgh, D. G.; Cooper, D. M. PhreePlot: Creating graphical output with PHREEQC. http://www.phreeplot.org. 2009.

31. Powell, M. J. D. A method for minimizing a sum of squares of non-linear functions without calculating derivatives. The Computer Journal, 1965, 7, 303-307.

32. Venema, P.; Hiemstra, T.; van Riemsdijk, W. H. Multisite Adsorption of Cadmium on Goethite. J. Coll. Int. Sci., 1996, 183, 515-527.

33. Lützenkirchen, J.; Marsac, R.; Kulik, D. A.; Payne, T. E.; Xue, Z.; Orsetti, S.; Haderlein, S. B. Treatment of multi-dentate surface complexes and diffuse layer implementation in various speciation codes. Appl. Geochem., 2015, 55, 128-137.

34. Johnson, B. B.; Sjöberg, S.; Persson, P. Surface Complexation of Mellitic Acid to Goethite: An Attenuated Total Reflection Fourier Transform Infrared Study. Langmuir, 2004, 20, 823-828

35. Norén, K.; Persson, P. Adsorption of monocarboxylates at the water/goethite interface: The importance of hydrogen bonding. Geochim. Cosmochim. Acta, 2007, 71, 57175730 .

36. Boily, J.-F.; Lützenkirchen, J.; Blamès, O.; Beattie, J.; Sjöberg, S. Modeling proton binding at the goethite ( $\alpha-\mathrm{FeOOH})$-water Interface. Colloids Surf. A, 2001, 179, 11-27.

37. Song X.; Boily, J.-F. Surface Hydroxyl Identity and Reactivity in Akaganéite J. Phys. Chem. C, 2011, 115, 17036-17045.

38. Song X.; Boily, J.-F. Competitive ligand exchange on akaganéite surfaces enriches bulk chloride loadings. J. Coll. Int. Sci., 2012, 376, 331-333.

39. IUPAC (2001) IUPAC Stability Constants Database. Version 5.4, IUPAC and Academic Software (acadsoft@bcs.org.uk).

40. Neugebauer, U.; Szeghalmi, A.; Schmitt, M.; Kiefer, W.; Popp, J.; Holzgrabe, U. Vibrational spectroscopic characterization of fluoroquinolones. Spectrochim. Acta, Part $A, \mathbf{2 0 0 5}, 61,1505-1517$. 
535

536

537

538

539

540

541

542

543

544

545

546

547

548

549

550

551

552

553

554

555

556

557

558

559

560

561

41. Tarushi, A.; Christofis, P.; Psomas, G. Synthesis, characterization and interaction with DNA of mononuclear metal complexes with oxolinic acid. Polyhedron, 2007, 26, 39633972.

42. Nakamoto, K. Infrared and Raman Spectra of Inorganic and Coordination Compounds. Part B: Applications in Coordination, Organometallic, and Biorganic Chemistry, 5th ed.; Wiley-Interscience: New York, 1997.

43. Yost, E. C.; Tejedor-Tejedor, M. I.; Anderson, M. A. In Situ CIR-FTIR Characterization of Salicylate Complexes at the Goethite/Aqueous Solution Interface. Environ. Sci. Technol., 1990, 24, 822-828.

44. Cooper, E. M.; Vasudevan, D. Hydroxynaphthoic acid isomer sorption on goethite. $J$. Col. Int. Sci., 2009, 333, 85-96.

45. Rusch, B.; Hanna, K.; Humbert, B. Sorption and Transport of Salicylate in a Porous Heterogeneous Medium of Silica Quartz and Goethite. Environ. Sci. Technol., 2010, 44, 2447-2453.

46. Hanna, K.; Boily, J.-F. Sorption of Two Naphthoic Acids to Goethite Surface under Flow through Conditions. Environ. Sci. Technol., 2010, 44, 8863-8869.

47. Boily, J.-F.; Persson, P.; Sjöberg, S. Benzenecarboxylate surface complexation at the goethite $(\alpha-\mathrm{FeOOH}) /$ water interface: II. Linking IR spectroscopic observations to mechanistic surface complexation models for phthalate, trimellitate, and pyromellitate. Geochim. Cosmochim. Acta, 2000, 64 (20), 3453-3470.

48. Yates, J. T. Jr.; Madey, T. E. Vibrational Spectroscopy of Molecules on Surfaces. Plenum Press, 1987.

49. Lai, H-T.; Chien, Y-H. ; Lin, J-S. Long-term transformation of oxolinic acid in water from an eel pond. Aquaculture, 2008, 275 (1-4), 96-101.

50. Psomas, G.; Tarushi, A.; Efthimiadou, E. K.; Sanakis, Y.; Raptopoulou, C. P.; Katsaros, N. Synthesis, structure and biological activity of copper(II) complexes with oxolinic acid. J. Inorg. Biochem., 2006, 100, 1764-1773. 
562 Table 1. Surface Complexation Model.

\begin{tabular}{|c|c|c|c|c|c|c|c|}
\hline \multirow{2}{*}{$\begin{array}{l}\text { Goethite }^{\mathbf{a}} \\
\equiv \mathrm{Fe}_{3} \mathrm{O}^{-0.5}+\mathrm{H}^{+} \rightleftharpoons \equiv \mathrm{Fe}_{3} \mathrm{OH}^{+0.5}\end{array}$} & \multirow{2}{*}{$\frac{\log K}{9.1}$} & \multirow{2}{*}{$\frac{\Delta \mathrm{z}_{0}}{+1}$} & \multirow{2}{*}{$\frac{\Delta \mathrm{z}_{1}}{0}$} & \multirow{2}{*}{$\frac{\Delta \mathrm{z}_{2}}{0}$} & \multicolumn{3}{|c|}{$\left(\right.$ Site $\left./ \mathrm{nm}^{2}\right)$} \\
\hline & & & & & 3.03 & 3.34 & - \\
\hline$\equiv \mathrm{Fe}_{3} \mathrm{O}^{-0.5}+\mathrm{H}^{+}+\mathrm{Cl}^{-} \rightleftharpoons \equiv \mathrm{Fe}_{3} \mathrm{OH}_{2}{ }^{+0.5 \cdots} \mathrm{Cl}^{-}$ & 8.1 & +1 & 0 & -1 & & & \\
\hline$\equiv \mathrm{Fe}_{3} \mathrm{O}^{-0.5}+\mathrm{Na}^{+} \rightleftharpoons \equiv \mathrm{Fe}_{3} \mathrm{OH}^{-0.5 \cdots} \mathrm{Na}^{+}$ & -1 & 0 & 0 & +1 & & & \\
\hline$\equiv \mathrm{FeOH}^{-0.5}+\mathrm{H}^{+} \rightleftharpoons \equiv \mathrm{FeOH}_{2}^{+0.5}$ & 9.1 & +1 & 0 & 0 & 3.03 & 3.34 & 7.4 \\
\hline$\equiv \mathrm{FeOH}^{-0.5}+\mathrm{H}^{+}+\mathrm{Cl}^{-} \rightleftharpoons \equiv \mathrm{FeOH}_{2}^{+0.5 \cdots} \mathrm{Cl}^{-}$ & 8.1 & +1 & 0 & -1 & & & \\
\hline$\equiv \mathrm{FeOH}^{-0.5}+\mathrm{Na}^{+} \rightleftharpoons \equiv \mathrm{FeOH}^{-0.5 \cdots} \mathrm{Na}^{+}$ & -1 & 0 & 0 & +1 & & & \\
\hline $2 \mathrm{H}^{+}+2 \equiv \mathrm{FeOH}^{-0.5}+\mathrm{OA}^{-} \rightleftharpoons\left(\equiv \mathrm{FeOH}_{2}\right)_{2}^{+\ldots}(\mathrm{OA})^{-}$ & $20.3 \pm 0.1^{\mathrm{c}}$ & +2 & -1 & 0 & & & \\
\hline $2 \mathrm{H}^{+}+2 \equiv \mathrm{FeOH}^{-0.5}+\mathrm{OA}^{-} \rightleftharpoons(\equiv \mathrm{Fe})_{2}(\mathrm{OA})^{0}+2 \mathrm{H}_{2} \mathrm{O}$ & $20.3 \pm 0.1^{\mathrm{c}}$ & +1 & 0 & 0 & & & \\
\hline Akaganéite $^{b}$ & $\log K$ & $\Delta \mathrm{z}_{0}$ & $\Delta \mathrm{z}_{1}$ & $\Delta \mathrm{z}_{2}$ & $(100$ & $\begin{array}{l}001) \\
\text { ite/nr }\end{array}$ & $(010)$ \\
\hline$\equiv \mathrm{FeO}^{-1.5}+\mathrm{H}^{+} \rightleftharpoons \equiv \mathrm{FeOH}^{-0.5}$ & 20.0 & +1 & 0 & 0 & & & - \\
\hline$\equiv \mathrm{FeO}^{-1.5}+2 \mathrm{H}^{+} \rightleftharpoons \equiv \mathrm{FeOH}_{2}^{+0.5}$ & 28.2 & +2 & 0 & 0 & & & \\
\hline$\equiv \mathrm{FeO}^{-1.5}+2 \mathrm{H}^{+}+\mathrm{Cl}^{-} \rightleftharpoons \equiv \mathrm{FeOH}_{2}^{+0.5 \cdots} \mathrm{Cl}^{-}$ & 29.2 & +2 & 0 & -1 & & & \\
\hline$\equiv \mathrm{FeO}^{-1.5}+\mathrm{H}^{+}+\mathrm{Na}^{+} \rightleftharpoons \equiv \mathrm{FeOH}^{-0.5 \cdots} \mathrm{Na}^{+}$ & 21.0 & +1 & 0 & +1 & & & \\
\hline $2 \mathrm{H}^{+}+2 \equiv \mathrm{FeOH}^{-0.5}+\mathrm{OA}^{-} \rightleftharpoons\left(\equiv \mathrm{FeOH}_{2}\right)_{2}^{+\ldots}(\mathrm{OA})^{-}$ & $21.5 \pm 0.1^{\mathrm{c}}$ & +2 & -1 & 0 & & & \\
\hline $2 \mathrm{H}^{+}+2 \equiv \mathrm{FeOH}^{-0.5}+\mathrm{OA}^{-} \rightleftharpoons(\equiv \mathrm{Fe})_{2}(\mathrm{OA})^{0}+2 \mathrm{H}_{2} \mathrm{O}$ & $21.5 \pm 0.1^{\mathrm{c}}$ & +1 & 0 & 0 & & & \\
\hline$\equiv \mathrm{Fe}_{3} \mathrm{O}_{\mathrm{I}}^{-0.5}+\mathrm{H}^{+} \rightleftharpoons \equiv \mathrm{Fe}_{3} \mathrm{O}_{\mathrm{I}} \mathrm{H}^{+0.5}$ & 11.7 & +1 & 0 & 0 & & & - \\
\hline$\equiv \mathrm{Fe}_{3} \mathrm{O}_{\mathrm{II}}^{-0.5}+\mathrm{H}^{+} \rightleftharpoons \equiv \mathrm{Fe}_{3} \mathrm{O}_{\mathrm{II}} \mathrm{H}^{+0.5}$ & 2.6 & +1 & 0 & 0 & & & - \\
\hline$\equiv \mathrm{Fe}_{2} \mathrm{O}^{-1}+\mathrm{H}^{+} \rightleftharpoons \equiv \mathrm{Fe}_{2} \mathrm{OH}^{0}$ & 10.8 & +1 & 0 & 0 & & & 7.06 \\
\hline$\equiv \mathrm{Fe}_{2} \mathrm{O}^{-1}+2 \mathrm{H}^{+} \rightleftharpoons \equiv \mathrm{Fe}_{2} \mathrm{OH}_{2}^{+}$ & 17.9 & +2 & 0 & 0 & & & \\
\hline$\equiv \mathrm{Fe}\left(\mathrm{OH}_{2}\right)(\mathrm{OH})^{0}+\mathrm{H}^{+} \rightleftharpoons \equiv \mathrm{Fe}\left(\mathrm{OH}_{2}\right)_{2}^{+}$ & 8.2 & +1 & 0 & 0 & & & 3.53 \\
\hline $\mathrm{H}^{+}+\equiv \mathrm{Fe}\left(\mathrm{OH}_{2}\right)(\mathrm{OH})^{0}+\mathrm{OA}^{-} \rightleftharpoons \equiv \mathrm{Fe}(\mathrm{OA})^{0}+2 \mathrm{H}_{2} \mathrm{O}$ & $13.9 \pm 0.1$ & 0 & 0 & 0 & & & \\
\hline
\end{tabular}

563

564

565

566

567

568

569

570

${ }^{\mathrm{a}} \mathrm{TPM}$ with $\mathrm{C}_{1}=2.3 \mathrm{~F} / \mathrm{m}^{2}, \mathrm{C}_{2}=1.07 \mathrm{~F} / \mathrm{m}^{2}$, surface area: $95 \mathrm{~m}^{2} / \mathrm{g} ; 63 \%$ of $(101), 27 \%$ of $(001)$ and $10 \%$ of (210). The HB surface complex is considered to form only at the (101) and (001) planes while the MB occurs at all planes.

${ }^{\mathrm{b}}$ TPM with $\mathrm{C}_{1}=2.3 \mathrm{~F} / \mathrm{m}^{2}, \mathrm{C}_{2}=1.6 \mathrm{~F} / \mathrm{m}^{2}$, surface area: $239 \mathrm{~m}^{2} / \mathrm{g} ; 95 \%$ of $(100) /(001)$ and $5 \%$ of $(010)$.

${ }^{\mathrm{c}}$ Constant and uncertainty obtained with Phreeplot, corrected according to Venema et al. ${ }^{32}$. 


\section{$571 \quad$ Figure captions}

572 Figure 1. OA removal from solution (molecule $/ \mathrm{nm}^{2}$ ) for $[\mathrm{OA}]_{\mathrm{tot}}=10 \mu \mathrm{M}$ on $50 \mathrm{~m}^{2} / \mathrm{L}$ goethite

573 (a) and akaganéite (b) versus $\mathrm{pHc}\left(=-\log \left[\mathrm{H}^{+}\right]\right)$at different $\mathrm{NaCl}$ concentrations. OA removal 574 from solution (molecule $/ \mathrm{nm}^{2}$ ) for $[\mathrm{OA}]_{\text {tot }}=50 \mu \mathrm{M}$ on $50 \mathrm{~m}^{2} / \mathrm{L}$ goethite $(\mathrm{c})$ and akaganéite (d) 575 in $100 \mathrm{mM} \mathrm{NaCl}$ versus $\mathrm{pH}\left(=-\log \left[\mathrm{H}^{+}\right]\right)$. The corresponding percentage of $\mathrm{OA}$ removal at the 576 plateau is also given. Lines are modeling results, where OA speciation on the solid phase is 577 shown for $[\mathrm{NaCl}]=100 \mathrm{mM}$ (legend in $\mathrm{a} / \mathrm{c}$ and $\mathrm{b} / \mathrm{d}$ is the same for the model). $\mathrm{MB}$ and $\mathrm{HB}$ 578 refer to metal- and hydrogen-bonded OA, respectively.

579

580 Figure 2. (a) Experimental and calculated OA solubility in $100 \mathrm{mM} \mathrm{NaCl}$ versus pHc. The 581 equilibrium $\mathrm{OA}$ concentration $\left([\mathrm{OA}]_{\mathrm{aq}}\right)$ in contact with goethite and akaganéite for $[\mathrm{OA}]_{\mathrm{tot}}=10$ 582 and $50 \mu \mathrm{M}$ in $100 \mathrm{mM} \mathrm{NaCl}$ are also plotted with modeling results. (b) OA-goethite and OA583 akaganéite sorption isotherms at $\mathrm{pHc}=6.1 \pm 0.1$ and $100 \mathrm{mM} \mathrm{NaCl}$. The results of the models 584 for goethite and akaganéite and OA speciation at the akaganéite surface are also shown. OA 585 solubility limit at $\mathrm{pHc}=6.1$ is shown as a vertical dashed line.

586

587 Figure 3. ATR-FTIR spectra of OA adsorbed to goethite (a) and akaganéite (b) for various $588 \mathrm{pHc}\left(-\log \left[\mathrm{H}^{+}\right]\right)$in $100 \mathrm{mM} \mathrm{NaCl}$ for $[\mathrm{OA}]_{\mathrm{tot}}=50 \mu \mathrm{M}$ (except for goethite at $\mathrm{pHc}=5.20$ and 5896.39 , where $\left.[\mathrm{OA}]_{\mathrm{tot}}=20 \mu \mathrm{M}\right)$. ATR-FTIR spectra of dissolved OA in $1 \mathrm{M} \mathrm{NaOH}\left(\mathrm{OA}_{(\mathrm{aq})}\right)$ and 590 protonated OA under its solid form $\left(\mathrm{OA}_{(\mathrm{s})}\right)$ are shown as references.

592 Figure 4. Possible surface complexes of OA at goethite and akaganéite surfaces. The 593 electronic structure of OA is proposed according to previous studies on metal-OA 594 compounds. $^{41,50}$ 

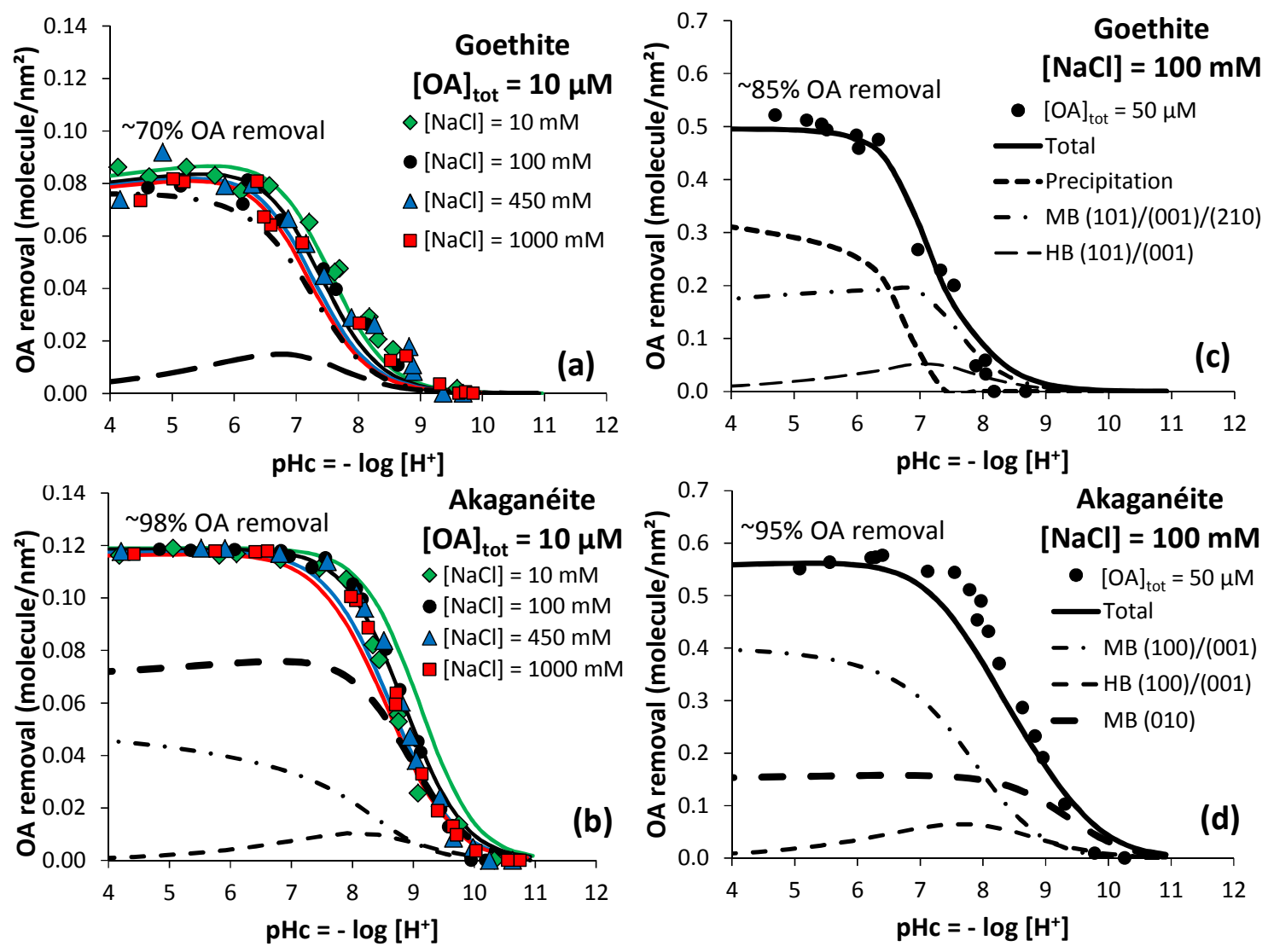

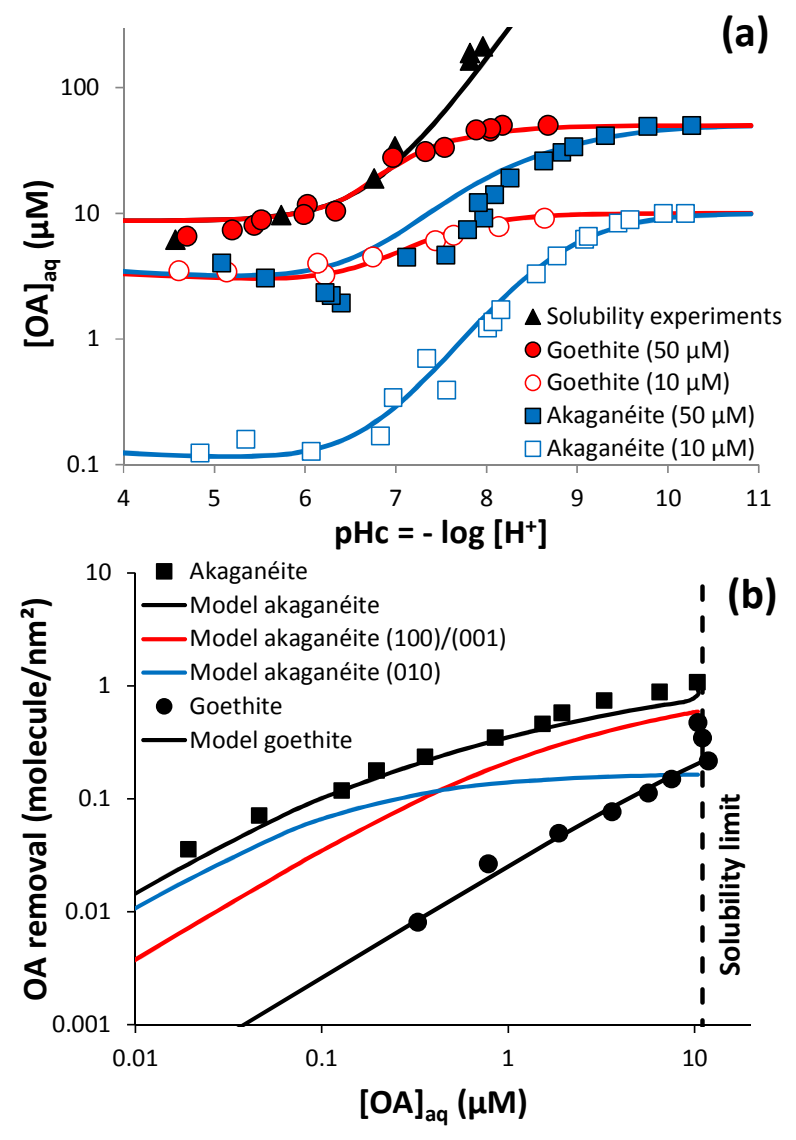

602

603 

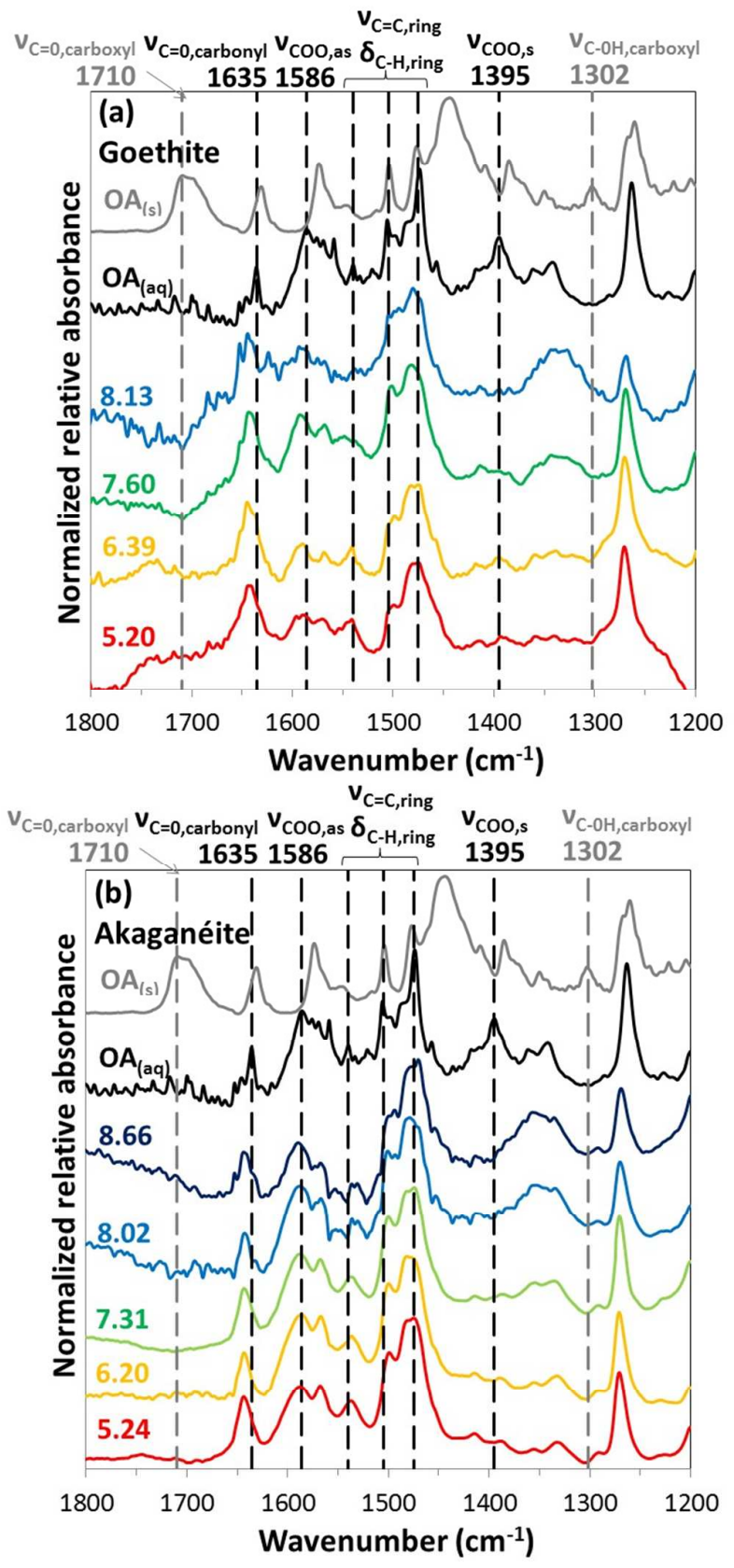

606 
607

608

609

\section{Figure 4}

(a)

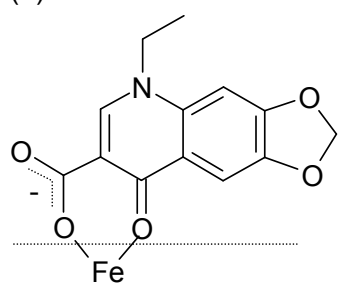

(b)

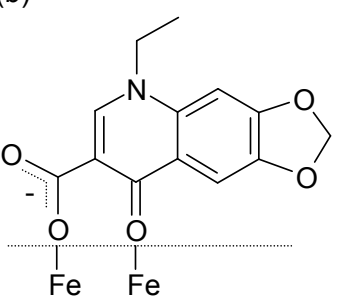

(c)<smiles>Cn1cc(C(=O)O)c(=O)c2cc3c(cc21)OCO3</smiles>

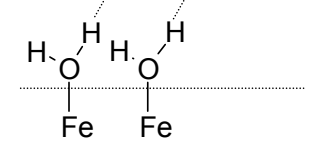


610

611

\section{TOC/abstract}

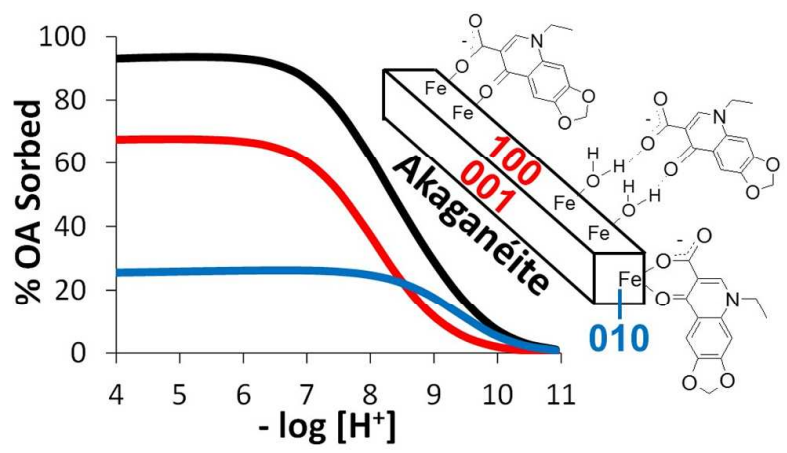

613 